\title{
Review of O'Donoghue, T. and O'Doherty, T., “Irish Speakers and Schooling in the Gaeltacht, 1900 to the Present" (2019), Palgrave Macmillan, London
}

\author{
An Dr Dónall P. Ó Baoill, \\ Ollamh Emeritus, Ollscoil na Banríona, Béal Feirste.
}

The contents of the book under review consist of an introduction and prologue (i-xxii), followed by ten chapters which present an overview of different aspects of the Irish language in the $19^{\text {th }}$ and $20^{\text {th }}$ centuries right up to the present (pp 1-238). The book places particular emphasis on the role of Irish in education with special reference to Gaeltacht areas. This is followed in turn by an Appendix (pp 239-240), a Bibliography (pp 241-256) and an Index (pp 257-265).

\section{Prologue}

The purpose of the book is to give a general overview of the decline of the Irish language with particular emphasis on the $19^{\text {th }}$ and $20^{\text {th }}$ centuries, including generous statistical information beginning with the 1851 census. The preparation of this publication is an attempt to rectify a deficit of not having any full-length account published thus far on the history of various aspects of life in the Gaeltacht and is specifically concerned with the schooling of Gaeltacht students from 1900 up to the present. The contribution made by the authors certainly fulfils that purpose.

The authors' own connection with Irish and their family background is outlined next. Irish was certainly not their first language at home and they had little chance of using it to any great extent in their immediate vicinity, apart from conversations with individuals from time to time who helped them improve the conversational ability and grammatical accuracy in the language.

Tom O'Donoghue began his undergraduate studies in England in the early 1970s. By his own admission, he paid little attention to his family background regarding Irish and had fallen out of the practise of speaking Irish. Later when he enrolled in what is now the University of Limerick in order to finish his degree, things changed a little. It was here that he met Dr. Gearóid Ó Crualaoich, head of the 'Irish Studies' programme in which he had enrolled. Dr Ó Crualaoich was an inspirational teacher and his enthusiasm for the Irish language re-awakened in O'Donoghue a great interest for the language. It took several more years for him to improve 
his ability to speak it. Ó Crualaoich instilled a new appreciation in O'Donoghue's mind of the multifaceted dimensions of Irish culture.

This book is dedicated to Gearóid Ó Crualaoich and Muiris Budhlaeir (RIP). When O'Donoghue returned to his native West Waterford in his early 20s as a secondary school teacher he became determined to improve the quality of his spoken Irish. He befriended many outstanding Irish speakers among them Muiris Budhlaeir (RIP), principal of Scoil na Leanaí in An Rinn. Muiris was a native of An Fearann in Corca Dhuibhne. It's little wonder then that when he first met his co-author Teresa O'Doherty and discovered that Muiris was her husband's uncle, that their mutual interests resulted in engaging academic work of the type which led eventually to the writing of this book.

O'Donoghue's own specific academic interest in the topic covered in this book arose as far back as 1984 while browsing through a special issue of Crane Bag devoted to various aspects of the Irish language. As he read the essay on education, it mentioned the introduction of a bilingual programme for schools in Irish-speaking districts. When he went back to check the secondary sources to find out more about this programme, it turned out to be of no avail. He then began to develop his own agenda on the matter and that is the subject matter of several sections of this book.

Teresa O'Doherty grew up in the town of Kilmallock, County Limerick. She was aware from an early age and especially through her primary school years of the great tradition and history of her native place. She was aware of the poetical tradition surrounding Filí na Máighe and attended Féile na Máighe in the 1970s as a member of her school choir.

This was fostered when she was growing up through attendance at the annual festival of culture, Féile na Máighe, which was held during the 1970s in County Limerick. She recalls singing the beautiful song 'Slán Cois Máighe' as part of her primary school choir. Her teachers at primary level introduced her to Irish song, poetry, language and Irish culture and this formed an important element in the school curriculum. It was in every sense a broad and holistic education.

She became a student at Mary Immaculate College and qualified as a primary teacher. She participated in the work of Irish college programmes as ceannaire (leader) teaching Irish songs and dances. She organised cycle trips to historic sites. and explored the historical landmarks 
and traditions of the Corca Dhuibhne area of West Kerry. She often took the boat to the Great Blasket Island.

Although this publication is the first book to appear that deals with the history of schooling in the Gaeltacht since 1900, the readers are encouraged to view it as 'providing the broad parameters to guide the development of a comprehensive research agenda for the field rather than constituting the last word on the subject.'

\section{Chapter 1 - The Gaeltacht: Constructed, Located and Promoted}

The specific focus of the book is the history of schooling of children in the Gaeltacht from 1900 to the present. It provides an overview on life in Gaeltacht districts and gives a very detailed account of the Irish colleges established by the Gaelic League beginning in 1900 for the teaching of adults. This helped to highlight the existence of the Gaeltacht in the public mind nationally. The emphasis in the book is on the Irish language in Ireland, and specifically in education.

This chapter goes on to review the development of the term Gaeltacht. The outcome of the 1956 Gaeltacht Commission was that the Gaeltacht was an officially defined geographical area confined to six counties. Since then only minor changes have taken place in the Gaeltacht boundaries. This involved the inclusion of a few small districts in Cork, Kerry and Ráth Chairn, Co. Meath. In 2002, the latest commission to examine the linguistic make-up of the Gaeltacht concluded that patterns of bilingualism were well developed and English was becoming the dominant language.

The Gaeltacht Bill 2012 was the next major change introduced by the Government and under the legislation all Gaeltacht communities were required to prepare and produce a language plan. These plans have now (2020) become a reality and all of them are now available or are in the process of becoming available on-line. However, they have not been referenced or discussed in this book.

The authors praise the work of the 'Irish colleges', as they came to be known as they regularly employed native speakers of Irish as well as local storytellers with a high reputation as performers and carriers of older Irish traditions. This certainly helped learners to appreciate the level of fluency to which they themselves might aspire. These institutions, eleven in all, were 
later recognised as institutions providing appropriate courses for the preparation of teachers of Irish.

The concept Gaeltacht, the authors conclude, was 'solidified and gained public acceptance during the early part of the twentieth century'. Furthermore, the Gaelic League and the establishment of Irish colleges in the Gaeltacht played a significant part in preserving the Gaeltacht.

\section{Chapter 2 - Education and the Irish Language in the Longue Durée}

To help people contextualise the many developments in education and the Irish language since 1900, the authors discuss the fate of Irish up until the advent of the Irish Free State in 1922. Irish in education up to 1831 is then considered. The rest of the chapter provides an overview of the place Irish held in National Schools up to 1904. The authors view the Great Famine as an event that acted in accelerating a major language shift already set in motion by economic and social pressure (see studies by Fitzgerald and Durkacz).

The authors pose a question which is hardly ever asked, namely, 'why did the acquisition of English mean, overwhelmingly, the abandonment of Irish?'. On a universal level one would expect a prolonged period of various types of bilingualism. This indeed opens up a major field of inquiry about Irish for other researchers to pursue.

Different political movements dominated the attention of the Irish people during the second half of the $19^{\text {th }}$ century although the revival of Gaelic culture and the promotion of Irish including all games associated with Ireland flourished. Despite efforts to introduce the home language in instruction for ease of understanding, it all fell on deaf ears.

The fact that the National Board of Education did not allow teaching through the medium of Irish in Irish-speaking districts and furthermore banned the teaching of Irish as a subject or its use as a medium in any schools under the National Board, had detrimental consequences for the language. It is claimed that the national schools did play a pivotal role in accelerating the decline of Irish language. The National Board's ban undoubtedly contributed to an Englishbased curriculum being established in Gaeltacht schools up until 1904. 


\section{Chapter 3 - "Saving the Child": The Gaelic League's Campaign for Bilingual Education for Irish-Speaking Districts}

This chapter outlines the achievements of the Gaelic League since its establishment in 1893 in promoting Irish within and without the educational system. By 1908 half of all secondary schools in Ireland were offering it as an examination subject. The League also succeeded in making Irish a compulsory subject to pass in the matriculation examination when seeking entry to any of the colleges attached to the National University of Ireland.

The rest of this chapter concerns itself with the introduction of the Bilingual Programme and its dissemination within Gaeltacht areas. The closing sections of the chapter give a succinct overview of the role the Gaelic League played in the preparation of teachers who wished to teach Irish-speaking children by means of bilingual methods.

The number of schools teaching the Bilingual Programme in Gaeltacht schools in 1908 was one hundred and ten (110). In 1922 the National Board estimated that 55\% of all schools in Irishspeaking districts were using and teaching the Bilingual Programme. The authors draw our attention to the reality that 'despite limited professional development and inadequate payment for the additional work involved, teachers in many parts of the country experienced quite a degree of success in teaching the Bilingual Programme'. However, they point out that by 1922 , only $49 \%$ of the teachers within the schools in the higher intensity Irish-speaking areas had the specialist qualification entitled 'the bilingual certificate'.

The authors also raise an interesting matter which still requires investigation - namely, a failure to address the question of how to teach English as a second language in schools in Irishspeaking districts in all teacher training colleges. Furthermore, the teacher training colleges at the time largely ignored the existence of the Bilingual Programme and had a more conservative approach to methods of promoting bilingual teaching in schools.

\section{Chapter 4 - Shifting Concern for "Saving the Child" to Concern About "Saving the Language": 1918-1926}

Things began to change as the Gaelic League began to advocate for changes in improving the status of Irish in all schools throughout the country regardless of home language usage. In Irishspeaking areas all subjects except English were to be taught through the medium of Irish. Irish history, music and dance were to be taught to all pupils. The Gaelic League had very little 
success in applying this new programme. In many instances, teachers were antagonised and 'bullied' into adopting the new approach.

Teaching in infant schools was to be undertaken entirely through the medium of Irish. The new Government decreed that from 17 March 1922, Irish was to be taught or used as a medium of instruction for a minimum of one hour a day. This presented an enormous challenge to teachers and in 1925 the government went about addressing the issues. It heralded the introduction of Preparatory Colleges. Defining Gaeltacht regions and presenting recommendations for the improvement of its economic standards and educating opportunities was addressed in the Report of Coimisiún na Gaeltachta (1926).

It would seem that the general overall conclusion arrived at was that there would be no improvement to conditions in the Gaeltacht until a large number of inadequacies in the spheres of economics and education were properly addressed and rectified. However, unemployment and emigration persisted in Gaeltacht areas and there was no attempt to bring much-needed investment to these regions.

\section{Chapter 5 - Schooling of Students from the Gaeltacht and the National Policy of "Saving the Language" Through All Primary Schools, 1922-1965}

The new primary school programme being taught in the early 1920s was no longer the "childcentred' programme which operated during the last two decades of British rule. The content and focus in all subjects were now very 'Ireland-centred' and furthermore the Irish language played a larger and pivotal role in infant classes. Further changes were introduced in 1926 and again in 1934. Although the Irish language gained a new status in the 1937 Irish Constitution, with Article 8.1 declaring it to be the first official language, there was a growing discontent among teachers due mainly to the imposition of a top-down approach to the teaching of Irish.

The Government soon realised that something had to be done 'to change the attitude of the people so that they would be keen to speak Irish to the children'. This resulted in a proposal in 1934 that a bonus of $£ 2$ per annum be paid to the parent or guardian of each child in attendance at a primary school in the Gaeltacht or Breac-Ghaeltacht between the ages of six and fourteen where the Department was satisfied that Irish was the language of the child's home and that the child spoke Irish naturally and fluently. 
Another important step was taken by Government in 1931 when a scholarship scheme for FíorGhaeltacht students was initiated. Only children whose home language was Irish and who had been educated through Irish were eligible to apply for these scholarships. Eight colleges were established to cater for the Gaeltacht pupils receiving scholarships. The majority were located within the Gaeltacht counties Donegal, Galway, Cork and Kerry and two in Dublin city. Colaiste Móibhí was a co-educational college and the rest were single sex catholic schools five for boys and two for girls. The strong emphasis on the Irish language during teaching hours and outside teaching times ensured that a Irish Gaelic ethos prevailed in these colleges.

By 1935 the influence of the preparatory colleges was recognisable. Changes to the recruitment policy followed in admitting students to training college were made in 1958 and henceforth shortlisting was based on Leaving Certificate results. This weakened the influence these colleges had in relation to entering training colleges and in 1960 the government decided to close the colleges - in hindsight a retrograde step perhaps!

\section{Chapter 6 - Marginalised Amongst the Marginalised: An Overview of Schooling in the Gaeltacht Up to the Mid-1960s}

Developments in relation to schooling in the Gaeltacht were discussed in detail in the previous two chapters covering the period 1922 to the mid-1960s. This chapter now turns to a deeper analysis of what has been reported. The first section compares the provision of education in the Gaeltacht and nationally. The mid- section analyses developments regarding education for those relocated from Gaeltacht areas to Ráth Chairn. The last section presents an overview of the efforts to revive Irish outside the Gaeltacht during the same period.

Although the number of students receiving post-primary education increased significantly throughout the 1950s, statistical analyses show that a large majority of that age group was still unaffected by it. In general, except for a small minority, post-primary schooling was not available to students from poorer sectors of Irish society. Furthermore, children of unskilled and semi-skilled manual workers benefited least from secondary school education. Hence, students from the lower classes were the least likely to obtain a university education and many dropped out of secondary education at a very early age.

The situation pertaining in the Gaeltacht pretty much portrays the same situation as has been described for areas elsewhere in Ireland. The provision of scholarships available to Gaeltacht 
children wishing to attend secondary-level schools was totally inadequate as an aid or incentive for a substantial number to pursue a secondary-level education.

By the end of the 1930s, due to the shrinkage of the language within the Gaeltacht and a realisation that the State's aspirations for Irish outside the Gaeltacht were not being realised, many individuals and interested groups had grave concerns about the maintenance and revival of Irish. Emigration was rife all over the country and this brought additional pressure to bear on economic and language planning.

After World War Two, the enthusiasm of the general public for the Irish language and its culture weakened considerably. The many reasons for this state of affairs are still in need of clarification. Furthermore, the emphasis on promoting the Irish language through the primary schools outside of the Gaeltacht was being resented by many students, teachers and parents.

In 1956, the State established Roinn na Gaeltachta (Department of the Gaeltacht) to increase its own role in relation to life in the Gaeltacht and to help stem the population drain. This was to be achieved by the provision of employment opportunities and essential supporting amenities. An improvement in living standards and conditions was expected to result. A further consequence of this departure was that the Gaeltacht areas were for the first time clearly defined.

\section{Chapter 7 - "You Don't Want to Be a Gaelic Dafty in This Town": Memories of Gaeltacht Residents on Their Schooling}

This chapter is a difficult one to summarise with any precision. The attitudes, memories and experiences being related are based on biographical works by different authors. They describe early childhood memories - their experience of schooling and local expectations in relation to schooling. A particular emphasis is placed on the culture of schooling in Ireland in the period 1922-1965. The chapter also investigates attitudes and memories among native speakers focusing specifically on the fact that Irish was their first language.

It was unusual for Gaeltacht students to attend secondary school, not to mention a boarding school, unless they succeeded in securing a Gaeltacht or Preparatory scholarship. To achieve this, pupils had to enter and score high on the entrance examinations to these colleges from an all-Ireland competition. However, after 1967/68 attending a secondary/post primary school 
became more prevalent due to the introduction by government of the so-called free education. A documentary on Coláiste Éinde broadcast on Telefís Éireann in 1974 revealed the changing patterns.

The next section outlines the experiences of various individuals while attending primary school and using Irish in later life outside a Gaeltacht environment. Cathal Ó Searcaigh, one or Ireland's foremost Irish language poets, gives a very depressing description in his memories of both primary and secondary level. He describes the 'grim, dispiriting' rooms where corporal punishment and maintenance of strict order were all-pervasive. His overall conclusion was that this type of pedagogy instilled in him the idea that 'knowledge was no more than factual cleverness'.

The majority or almost all of the autobiographical works by Gaeltacht authors do not indicate ignorance of being able to speak English on leaving primary schools. This claim however needs further investigation and research to back up this claim. Various authors describe a situation which prevailed well into the $20^{\text {th }}$ century where monolingual or near monolingual Irish speakers could not conduct or negotiate their business at fairs etc, without assistance of what they termed 'fear an Bhéarla' - probably equivalent to modern day interpreters. Dialect differences are also often mentioned as a hindrance. People recall an amount of confusion being created in the minds of many school goers because of a certain lack of agreement between the vocabulary, grammar and the manner or style of verbal expression in their native dialect rather than the 'standard' found in written pedagogical texts used by school teachers.

Ó Searcaigh remarks that while working in England native speakers overcame many of their difficulties. Their difficulties however amounted to a continuous linguistic struggle which they resented. This resulted in many of them being ashamed of the language and refusing to utter a word of Irish for fear of ridicule.

A small educated and committed group of Gaeltacht people organised themselves under the umbrella 'Cearta Sibhialta na Gaeltachta' (the Gaeltacht Civil Rights Movement) in the 1960s and became more assertive in demanding rights for all Gaeltacht inhabitants - demands that could not go unheeded. A network of parish councils evolved all over the Gaeltacht which resulted in improved communication and a new cohesion developed between Gaeltacht communities. There was a specific demand for a Gaeltacht Authority to integrate social and 
economic development (Ó Tuathaigh). This eventually materialised in 1979 as Údarás na Gaeltachta (the Gaeltacht Authority).

Despite this new development, no local government structures were developed to address specific issues relating to the Gaeltacht and the Gaeltacht communities were not given any statutory powers and hence had no control over their own lives. Despite many changes over the last 40 years this still remains the status quo.

\section{Chapter 8 - From Cultural Nationalism to Human Capital Production: Schooling in the Gaeltacht in a Changing Ireland, 1967-1998}

The implementation of the State's new economic policies began with the appointment of Seán Lemass as Taoiseach in 1959. Improvement in all economic spheres became a priority and this in turn meant parallel improvements and expansion in all educational sectors.

There was an increasing awareness within the Department of Education at this time of the importance of planning in relation to the provision of education facilities. In 1965 the government proposed that the purpose and content of education be reformed in order to meet the needs of the national economy. It furthermore illustrated the social and geographic inequalities of education opportunity that existed in Ireland. By 1973, however, following the introduction of 'free' post-primary education, $75 \%$ of all 15-year-olds were attending school. The Commission on the Restoration of the Irish Language was established in 1963. The government furthermore agreed that the preservation and strengthening of the Gaeltacht were essential in trying to restore the Irish language nationally.

Many of the developments which took place during the period 1960-1980 were indeed praiseworthy, but modest in nature and fell far short of what was required. There were very few dynamic developments suitable to cater for the special sensitive nature of problems within Gaeltacht communities and on the whole the policy followed only led to the increasing influence of English.

The success of Cearta Sibhialta na Gaeltachta (the Gaeltacht Civil Rights Movement), in the 60 s and early 70s has already been mentioned and their achievements were pivotal in the setting up of Raidió na Gaeltachta in 1972, Údarás na Gaeltachta in 1979 and Teilifís na Gaeltachta in 1996. 
Several administrative policies relating to primary schools were introduced during the late 1960s and into the 1970s, namely, the closure of small schools. Larger schools would result in better use of teacher resources and enable the implementation of a new child-centred curriculum. There was much resistance to this policy in the Gaeltacht and around the country. The most celebrated case of local protest was that related to Scoil Dhún Chaoin (Dunquin National School) in the Corca Dhuibhne Gaeltacht district in West Kerry. The Fianna Fáil government announced in the early 1970s it was closing the school. Locals objected vehemently and through their actions locally and nationally and the work of volunteer teachers kept the school open. In 1973, Richard Burke, Minister of Education opened the school officially.

In 1980, the Minister for Education formed An Comhchoiste um Oideachas sa Ghaeltacht (the Joint Committee for Education in the Gaeltacht) to examine education issues in the Gaeltacht. Gaeltacht schools were small and ill-equipped - there was a dearth of suitable textbooks and resources. The Comhchoiste recommended that an entirely different curriculum be introduced. The national Curriculum and Examinations Board was established in 1984. There was now more optimism that things might change. With regard to the Gaeltacht, it was recommended that a learner-centred communicative approach to the teaching of Irish be developed for use in all schools, both in Gaeltacht and in non-Gaeltacht districts. Once again, however, little came of this, and all schools returned to the status quo.

A large section of this chapter deals with changes in the Post-Primary sector, including governance issues, during the same period. Its description is wide-ranging and detailed and the interested reader should refer to the book. Various school models were developed in Gaeltacht and non-Gaeltacht areas due to various amalgamations during this period - Scoileanna Cuimsitheacha (Comprehensive Schools), Scoileanna Pobail (Community Schools) and Coláistí Pobail (Community Colleges).

Throughout the 1970s, 1980s and 1990s, various surveys amongst the population nationally showed a growing positive attitude towards the Irish language and reported support for the teaching of Irish in schools. Furthermore, the importance of the language as a cultural and ethnic symbol were increasingly positive. 


\section{Chapter 9 - A New Multilingual Ireland and Schooling in the Gaeltacht:1998 to the Present}

The 1980s in Ireland was a period of high unemployment and mass emigration for most of the 1980s. A period of prosperity followed up to the mid-2000s. Within the next decade the country faced a severe financial crisis. During the economic boom of the 1990s, Ireland witnessed a great influx of migrant workers and asylum seekers. This brought huge growth in ethnic and cultural diversity not to mention multilingualism. It also stimulated a significant amount of controversial discussion in the media. One primary focus was the rejection by some of the link between national identity and the Irish language. During the period under consideration, the State has taken a renewed interest by taking steps to try to halt the loss of the Irish language and re-establish it as a language of everyday communication.

Three years after the passing of the Education Act in 1998, the Irish Government issued a statement emphasising the importance of both the preservation and promotion of the Irish language in the Gaeltacht, in Irish society generally and amongst the Irish diaspora. In 2007, Irish became an 'official language of the European Union'.

Government action continues with the development of The 20-year Strategy for the Irish Language 2010-2030. The aim of this document is to heighten visibility of Irish in society as well as encouraging and increasing its use in public discourse and services.

A Comprehensive Linguistic Study on the Use of Irish in the Gaeltacht appeared in 2007. Its conclusions were rather stark - 'without urgent remedial work, the Irish language might disappear as a community or home language in the Gaeltacht within 15-20 years'. The Government's response was to pass the Gaeltacht Act (2012).

In order to rectify the shortage of teachers competent to teach through the medium as outlined in the Gaeltacht Education Policy 2017-2022 paper, the Department of Education and Skills established Aonad un Oideachas Gaeltachta (Gaeltacht Education Unit) in 2017. As a result, two new teacher education programmes were established (a) a four-year bachelor of education degree for primary teachers delivered entirely through the medium was launched in 2018 and (b) a master's programme for practising primary and post-primary teachers teaching in Irishmedium schools is being offered by Mary Immaculate College, Limerick. 


\section{Chapter 10 - Looking Backwards}

This chapter offers a short overview of the contents outlined and analysed in this book, namely, the schooling of children living in the Gaeltacht, with particular reference to the period from 1900 to the present. As the Chapter headings suggest, this outlines in some detail the historical, geographical and linguistic background and very specifically educational factors which influenced educational and linguistic matters in the Gaeltacht areas.

\section{Overall conclusion}

This is an important and timely publication. It certainly achieves its main objective as outlined in the Prologue, 'to rectify a deficit of not having any full-length account published thus far on the history of various aspects of life in the Gaeltacht and is specifically concerned with the schooling of Gaeltacht students from 1900 up to the present'. It is comprehensive in nature with detailed endnotes and an extensive bibliography.

Sociologists and applied linguists working and teaching in an Irish context with specific reference to the Gaeltacht areas should continue to research, analyse and provide additional overviews of current developments relating to the Irish language in its current context.

This book provides all researchers including postgraduate students of the sociolinguistics of Irish with a large amount of information conveniently organised, discussed and analysed. Those involved in current on-going educational research, including in particular language planning in the Gaeltacht and Irish medium education and planning outside the Gaeltacht will find much in this book to inform and guide them as they engage in issues related to the study of these disciplines and the preparation and application of practical programmes to engage with Irish society in general. Many of the familiar elements and current problems familiar to researchers, educators and language planners regarding the Irish language are clearly echoed in the narrative of this book and may provide useful guidance on how to solve various problems and difficulties in a progressive and intelligent manner. Social media may also play a significant role in popularising the language not only in its national context but also internationally.

Tá mórán Éireann sa leabhar seo nach bhfuil spás ann lena lua sa léirmheas seo. Cúis misnigh agus uchtaigh do gach duine ar spéis leo an scéal an bealach ina gcuirtear ábhar an leabhair i láthair agus ina bpléitear é. Is fiú do lucht pleanála teanga sna cheantair Ghaeltachta tagairt don leabhar seo agus do na moltaí atá ann. Bímis buíoch do na húdair as a leithéid a chur ar fáil. 
If and when a second edition of this important publication is contemplated, I would strongly recommend that an Irish language editor be employed to standardize and correct many errors of spelling of Irish names, surnames, placenames and committee and institutional names. Quotations of original printed materials should be carefully checked including translation from Irish to English and vice versa. I give below a sample list of what I have in mind.

P. xii Baile na Boc > Baile na bPoc.

P. xiii Conchubhair Ó Máille > Conchubhar Ó Máille

P. 11 Béal Átha'n Ghaorthaidh >> Béal Átha an Ghaorthaidh (see Logainm.ie).

P. 15 Note 45 'the módh díreach' >> 'the modh díreach'.

P. 20 Art Mac Cubhthaigh's poem - a fhoirfeadh dom fhían > a fhoirfeadh dom phian

P. 34 'An bhfuil i bhfad ag teacht ar scoil? >> 'An bhfuil tú i bhfad ag teacht ar scoil?

P. 41 Rotha Mór on Tsaoil >> Rotha Mór an tSaoil

P. 111 Coláiste Chaoímhín >> Coláiste Chaoimhín

P. 116 Béal a' Mhuirid >> Béal an Mhuirthead

P. 118 An Seana Phobal and An Seanphobal - a choice needs to be made between a standard form and a phonetically written form.

P. 119 Fleadh Cheól na hÉireann > Fleadh Cheoil na hÉireann

P. 126 Ros a’ Mhíl >> Ros an Mhíl

P. 143 Máirtin Ó Cadhain > Máirtín Ó Cadhain

P. 150 An Brátháir Ó Coileáin > An Bráthair Ó Coileáin

P. 151 Roinn na Gaeltacht $>$ Roinn na Gaeltachta

P. 156 at Ghort a' Choirce $>>$ at Gort an Choirce

P. 157 Coláiste Einde > Coláiste Éinde

P. 158 Quotation from Maidhc Dainín Ó Sé's book .... a thabharfadhdh....múinetóirí and in the English version of another phrase .... you would wear a while short and tie $>>$ you would wear a white shirt and tie

P. 195 An Chomhchoiste um Oideachas sa Ghaeltacht $\gg$ An Comhchoiste um Oideachas sa Ghaeltacht

P. 214 The phrase 'Including in the Gaeltacht' repeated in Title. 